\title{
长苞铁杉中木脂素类化学成分研究
}

\author{
刘贵园 ${ }^{a}$ 郭大乐 ${ }^{b}$ 邓文武 $b$ 令狐浪 ${ }^{a}$ \\ 张茂生 ${ }^{a}$ 何芋歧 ${ }^{a}$ 肖世基* ${ }^{*} a$ \\ ( ${ }^{a}$ 遵义医科大学药学院 贵州遵义 563006) \\ ( ${ }^{b}$ 成都中医药大学药学院 成都 611137)
}

\begin{abstract}
摘要 从中国特有植物长苞铁杉心材中分离纯化得到 1 个新的苄基呋喃酮衍生物(1), 2 个新的木脂素 $(\mathbf{2}, \mathbf{3})$, 以及 19 个 已知的木脂素类化合物，新化合物的结构通过 HR-ESI-MS，1D NMR，2D NMR，CD 等光谱技术分别鉴定为 3-(4'-羟基 -3'-甲氧基苄基)-2(5H)-呋喃酮(1)，(8S,8'S)-3,3'-二甲氧基木脂-4,4',9,9'-四醇-9-乙酸酯(2)，(7' $\left.R, 8 S, 8^{\prime} S\right)$-3',5-二甲氧基-2,7'环木脂-4,4', 9'-三醇-9-酸丁酯. 噻唑蓝(MTT)法测试显示新化合物对三种肿瘤细胞(A172, SHSY5Y, Hela)均未表现出明 显毒性. 斑马鱼肠胃蠕动活性测试显示, 化合物 3 在 8 和 $24 \mu \mathrm{mol} / \mathrm{L}$ 浓度下对斑马鱼肠胃蠕动有明显的促进作用. 关键词 松科; 长苞铁杉; 苄基呋喃酮; 木脂素
\end{abstract}

\section{Lignans from the Heartwood of Nothotsuga longibracteata}

\author{
Liu, Guiyuan ${ }^{a} \quad$ Guo, Dale ${ }^{b} \quad$ Deng, Yun ${ }^{b} \quad$ Linghu, Lang $^{a}$ \\ Zhang, Maosheng ${ }^{a} \quad \mathrm{He}$ Yuqi $^{a} \quad \mathrm{Xiao}^{a}$ Shiji $^{*, a}$ \\ ( ${ }^{a}$ School of Pharmacy, Zunyi Medical University, Zunyi, Guizhou 563006) \\ ( ${ }^{b}$ School of Pharmacy, Chengdu University of Traditional Chinese Medicine, Chengdu, 611137)
}

\begin{abstract}
Hydroxy-3'-methoxybenzyl)-2(5H)-furanone (1), a rare benzyl furanone derivate, and two new lignans (2 and 3) were isolated from the heartwood of Nothotsuga longibracteata, together with nineteen known lignans compounds. The structures and absolute configurations of the undescribed compounds were elucidated on the basis of HR-ESI-MS, 1D NMR, 2D NMR, and CD spectroscopies. The cytotoxic effects of the isolated new lignan compounds on three human tumour cell lines (A172, SHSY5Y, and Hela) were evaluated by methyl thiazolyl tetrazolium (MTT) assay. Their showed no cytotoxic activities at the concentration of $50 \mu \mathrm{mol} / \mathrm{L}$. Gastrointestinal motility test of zebrafish showed that compound $\mathbf{3}$ has the function of promoting gastrointestinal motility of zebrafish to excrete Nile red at doses 8 and $24 \mu \mathrm{mol} / \mathrm{L}$ by means of acting on the cholinergic nervous system.
\end{abstract}

Keywords pinaceae; Nothotsuga longibracteata; benzyl furanone; lignans

\section{Introduction}

Nothotsuga longibracteata (W. C. Cheng) Hu ex C. N. Page belongs to Nothotsuga of Pinaceae, one of Chinese rare gymnosperms endemic plant. Nothotsuga contains only one species, $N$. longibracteata, commonly known as the Bristlecone Hemlock, Tsuga longibracteata, Tsugo-keteleeria longibracteata. It was an archaic plant of the quaternary glacial period, and distributed mainly in Hunan, Guangdong, Guangxi, Fujian and Guizhou provinces of China. ${ }^{[1]}$ Plants of this genus have long been used as a traditional herbal medicine to treat arthritis and stomach trou- bles. $^{[2]}$ Previous chemical investigation of this plant afforded lanostane triterpenoids, lignans, flavonoids, sterols, and phenolic acids. ${ }^{[3-4]}$ Aiming to identify structurally interesting metabolites from Chinese endemic medical plants, ${ }^{[5-8]}$ we conducted an intensive investigation into the constituents of the heartwood of $N$. longibracteata. In this study, we report the isolation and structure elucidation of a rare benzyl furanone derivate, 3-(4'-hydroxy-3'-methoxybenzyl)-2(5H)-furanone (1), and two new lignans $\mathbf{2} \sim \mathbf{3}$, together with nineteen known lignans compounds $4 \sim 22$ (Figure 1). The structures of these new compounds were elucidated by spectroscopic evidences including HR-ESI-

* Corresponding author. E-mail: sjxiao@zmu.edu.cn

Received March 8, 2020; revised April 23, 2020; published online May 7, 2020.

Project supported by the National Natural Science Foundation of China (No. 31560102).

国家自然科学基金(No. 31560102)资助项目. 
MS, 1D, 2D NMR, and CD spectroscopies. The cytotoxic effects of the isolated new compounds on three human tumour cell lines (A172, SHSY5Y, and Hela) were evaluated by the MTT assay. But their showed no cytotoxic activities at the concentration of $50 \mu \mathrm{mol} / \mathrm{L}$. Gastrointestinal motility of zebrafish test showed that compound $\mathbf{3}$ has the function of promoting gastrointestinal motility of zebrafish to excrete Nile red at doses 8 and $24 \mu \mathrm{mol} / \mathrm{L}$ by means of acting on the cholinergic nervous system. We herein present the purification, structural elucidation, and biological evaluation of these isolated and identified lignans compounds.

\section{Results and discussion}

\subsection{Structure identification of compound 1}

Compound 1 was obtained as a brown gum. With the molecular formula, $\mathrm{C}_{12} \mathrm{H}_{12} \mathrm{O}_{4}$, which indicated 7 degrees of unsaturation, was established from the ion of protonated molecule peak at $m / z 221.0809[\mathrm{M}+\mathrm{H}]^{+}$(calcd for $\left.\mathrm{C}_{12} \mathrm{H}_{13} \mathrm{O}_{4}^{+}: 221.0808\right)$ in the HR-ESI-MS. The IR spectrum of compound $\mathbf{1}$ indicated the presence of hydroxyl and carbonyl groups at 3426 and $1746 \mathrm{~cm}^{-1}$. ${ }^{1} \mathrm{H}$ NMR, ${ }^{13} \mathrm{C}$ NMR and heteronuclear single quantum correlation (HSQC) spectra (Table 1) of compound 1 showed the presence of a 1,3,4-trisubstituted benzyl unit at $\delta_{\mathrm{H}} 6.72(\mathrm{dd}$,
$J=8.0,1.8 \mathrm{~Hz}, 1 \mathrm{H}), 6.76(\mathrm{~d}, J=1.8 \mathrm{~Hz}, 1 \mathrm{H}), 6.86(\mathrm{~d}, J=$ $8.0 \mathrm{~Hz}, 1 \mathrm{H}$ ), 3.52 (br. s, $2 \mathrm{H}$ ), and $\delta_{\mathrm{C}} 129.4,111.7,146.8$, $144.7,114.7,121.7,31.7$; a methylene group at $\delta_{\mathrm{H}} 3.52$ $\left(2 \mathrm{H}\right.$, brs) and $\delta_{\mathrm{C}} 31.7$; an oxygenated methylene group at $\delta_{\mathrm{H}} 4.75(\mathrm{~m}, 2 \mathrm{H})$ and $\delta_{\mathrm{C}} 70.5$; an olefinic bond at $\delta_{\mathrm{H}} 6.95(\mathrm{~m}$, $1 \mathrm{H})$ and $\delta_{\mathrm{C}} 134.8,145.6$; a methoxyl group at $\delta_{\mathrm{H}} 3.87(3 \mathrm{H}$, s) and $\delta_{\mathrm{C}} 56.1$; a carbonyl group at $\delta_{\mathrm{C}} 174.2$ and a hydroxyl group at $\delta_{\mathrm{H}}$ 5.58. These NMR data above indicated that compound 1 might be a benzylbutyrolactone derivative. ${ }^{[9]}$ The heteronuclear multiple-bond correlations (HMBC) (Figure 2) of $\mathrm{OCH}_{3}\left(\delta_{\mathrm{H}} 3.87\right)$ with C-3' $\left(\delta_{\mathrm{C}} 146.8\right), 4^{\prime}-\mathrm{OH}$ $\left(\delta_{\mathrm{H}} 5.58\right)$ with C-3', C-4' and C-5', and H-6' with C-4' $\left(\delta_{\mathrm{C}}\right.$ 146.8), indicated that the methoxyl group located at C-3' and hydroxyl group located at $\mathrm{C}-4$ '. The HMBC correlations of H-7' with C-1', C-2' and C-6', H-6' with C-7', and $\mathrm{H}-2$ ' with $\mathrm{C}-\mathrm{7}^{\prime}$ confirmed the presence of a benzyl moiety in the molecule. The HMBC correlations of $\mathrm{H}-4$ with $\mathrm{C}-2$ and C-5, H-5 with C-2, C-3 and C-4 established the presence of a furanone ring. Further, the connection of the benzyl moiety and the furanone ring by $\mathrm{C}-3$ and $\mathrm{C}-\mathrm{7}^{\prime}$, was established based on the HMBC correlations of $\mathrm{H}-7$ ' with C-2, C-3 and C-4, and H-4 with C-7'. Therefore, the structure of compound 1 was established as 3-(4'-hydroxy-3'methoxy-benzyl)-2(5H)-furanone.<smiles>COc1cc([C]c2ccc(C[C@@H](COC(C)=O)[C@@H](CO)Cc3ccc(O)c(OC)c3)c(OC)c2)ccc1O</smiles>

2<smiles>CCCCOC(=O)[C@H]1[CH]c2cc(OC)c(O)cc2[C@@H](c2cccc(O)c2)[C@H]1CO</smiles>

3

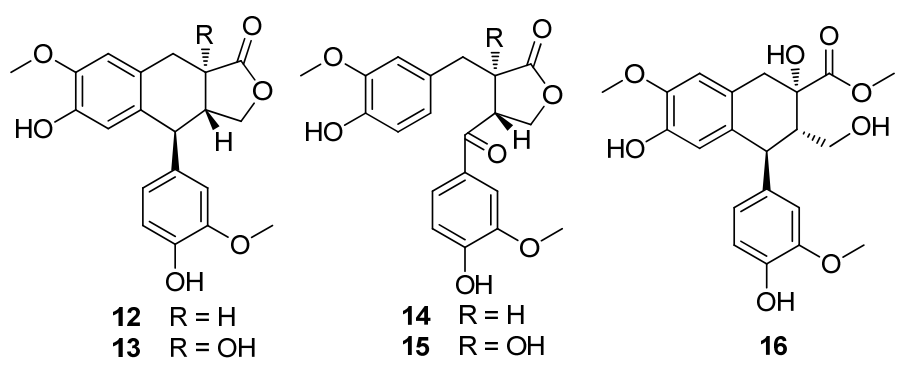<smiles>COc1cc(C[C@@H]2COC(=O)[C@]2(O)Cc2ccc(O)c(OC)c2)ccc1O</smiles><smiles>[R][R]Oc1ccc([R]([R])([H])C2COC(=O)C2([R7])Cc2ccc(O)c(OC)c2)cc1OC</smiles><smiles>[R]O[C@H]1OC[C@@H]2[C@@H](c3ccc(O)c(OC)c3)c3cc(O)c(OC)cc3C[C@H]12</smiles>

$\mathrm{H} \quad \mathrm{H} \quad \mathrm{H}$

$\mathrm{OH} \quad \mathrm{H} \quad \mathrm{H}$

$6 \mathrm{H}^{\mathrm{O}} \mathrm{OCH}_{3} \mathrm{H}$

$\begin{array}{llll}7 & \mathrm{H} & \mathrm{H} & \mathrm{OCH}_{2} \mathrm{CH}_{3}\end{array}$

$8 \mathrm{H} \quad \mathrm{H} \quad \mathrm{OH}$

$\mathrm{OH} \quad \mathrm{H}$

$10 \mathrm{R}=\mathrm{CH}_{3}$

$11 \mathrm{R}=\mathrm{CH}_{2} \mathrm{CH}_{3}$<smiles>COc1cc([C@H]2c3cc(O)c(OC)cc3C[C@@H](CO)[C@H]2CO)ccc1O</smiles><smiles>COc1cc([C@H]2c3cc(O)c(OC)cc3C[C@@H](CO)[C@H]2CO)ccc1O</smiles>

19<smiles>COc1cc(C[C@@H]2COC[C@H]2C(O)c2ccc(O)c(OC)c2)ccc1O</smiles>

20<smiles>COc1cc([C@H]2Oc3c(O)cc(CCCO)cc3C2CO)ccc1O</smiles><smiles>COc1cc([C@@H](O)[C@@H]2COC(=O)[C@@H]2Cc2cc(OC)c3c(c2)[C@H](CO)[C@@H](c2ccc(O)c(OC)c2)O3)ccc1O</smiles>

Figure 1 Chemical structures of compounds $\mathbf{1} \sim \mathbf{2 2}$ 
Table $1 \quad{ }^{1} \mathrm{H}$ NMR and ${ }^{13} \mathrm{C}$ NMR spectral data of compounds 1 and $2(400 / 100 \mathrm{MHz})$

\begin{tabular}{|c|c|c|c|c|}
\hline \multirow{2}{*}{ Position } & \multicolumn{2}{|l|}{$1\left(\mathrm{CDCl}_{3}\right)$} & \multicolumn{2}{|l|}{$2\left(\mathrm{CD}_{3} \mathrm{OD}\right)$} \\
\hline & $\delta_{\mathrm{H}}(J$ in $\mathrm{Hz})$ & $\delta_{\mathrm{C}}$ & $\delta_{\mathrm{H}}(J$ in $\mathrm{Hz})$ & $\delta_{\mathrm{C}}$ \\
\hline 1 & & & & 133.3 \\
\hline 2 & & 174.2 & 6.62 (br. s, $1 \mathrm{H})$ & 113.3 \\
\hline 3 & & 134.8 & & 148.9 \\
\hline 4 & $6.94 \sim 6.96(\mathrm{~m}, 1 \mathrm{H})$ & 145.6 & & 145.7 \\
\hline 5 & $4.74 \sim 4.76(\mathrm{~m}, 2 \mathrm{H})$ & 70.5 & 6.69 (overlapped, $1 \mathrm{H})$ & 115.9 \\
\hline 6 & & & 6.54 (overlapped, $1 \mathrm{H})$ & 122.8 \\
\hline 7 & & & $2.54 \sim 2.68(\mathrm{~m}, 2 \mathrm{H})$ & 35.9 \\
\hline 8 & & & $2.12 \sim 2.21(\mathrm{~m}, 1 \mathrm{H})$ & 40.5 \\
\hline 9 & & & $4.24(\mathrm{dd}, 11.1,5.9,1 \mathrm{H}) ; 4.01(\mathrm{dd}, 11.1,6.5,1 \mathrm{H})$ & 66.2 \\
\hline $1^{\prime}$ & & 129.4 & & 133.8 \\
\hline $2^{\prime}$ & $6.76(\mathrm{~d}, 1.8,1 \mathrm{H})$ & 111.7 & 6.56 (overlapped, $1 \mathrm{H})$ & 113.5 \\
\hline $3^{\prime}$ & & 146.8 & & 149.0 \\
\hline $4^{\prime}$ & & 144.7 & & 145.8 \\
\hline $5^{\prime}$ & $6.86(\mathrm{~d}, 8.0,1 \mathrm{H})$ & 114.7 & 6.59 (overlapped, $1 \mathrm{H})$ & 116.0 \\
\hline $6^{\prime}$ & $6.72(\mathrm{dd}, 8.1,1.8,1 \mathrm{H})$ & 121.7 & 6.54 (overlapped, $1 \mathrm{H})$ & 122.8 \\
\hline $7^{\prime}$ & 3.52 (br. s, $2 \mathrm{H})$ & 31.7 & $2.54 \sim 2.68(\mathrm{~m}, 2 \mathrm{H})$ & 35.6 \\
\hline $8^{\prime}$ & & & $1.89 \sim 1.98(\mathrm{~m}, 1 \mathrm{H})$ & 44.4 \\
\hline $9^{\prime}$ & & & $3.68(\mathrm{dd}, 10.8,6.0,1 \mathrm{H}) ; 4.01(\mathrm{dd}, 10.8,6.5,1 \mathrm{H})$ & 62.8 \\
\hline $1 "$ & & & & 173.1 \\
\hline $2^{\prime \prime}$ & & & $2.05(\mathrm{~s}, 3 \mathrm{H})$ & 21.1 \\
\hline $3-\mathrm{OCH}_{3}$ & & & $3.76(\mathrm{~s}, 3 \mathrm{H})$ & 56.3 \\
\hline $3^{\prime}-\mathrm{OCH}_{3}$ & $3.87(\mathrm{~s}, 1 \mathrm{H})$ & 56.1 & $3.77(\mathrm{~s}, 3 \mathrm{H})$ & 56.3 \\
\hline 4'-OH & $5.58(\mathrm{~s}, 1 \mathrm{H})$ & & & \\
\hline
\end{tabular}

\subsection{Structure identification of compound 2}

Compound 2 was isolated as a brown gum, with the molecular formula of $\mathrm{C}_{22} \mathrm{H}_{28} \mathrm{O}_{7}$ on the basis of HR-ESI-MS $\left(m / z \quad 427.1714 \quad[\mathrm{M}+\mathrm{Na}]^{+}\right.$, calcd for $\mathrm{C}_{22} \mathrm{H}_{28} \mathrm{O}_{7} \mathrm{Na}$ 427.1733,), which indicated 9 degrees of unsaturation. The IR spectrum of compound $\mathbf{2}$ indicated the presence of carbonyl group at $1767 \mathrm{~cm}^{-1}$. The ${ }^{1} \mathrm{H}$ NMR, ${ }^{13} \mathrm{C} \mathrm{NMR}$ and HSQC spectra (Table 1) of compound $\mathbf{2}$ displayed two 1,3,4-trisubstituted benzyl units at $\delta_{\mathrm{C}} 133.3,113.3,148.9$, $145.7,115.9,122.8$, and $\delta_{\mathrm{C}} 133.8,113.5,149.0,145.8$, $116.0,122.8$; two aryl methoxyl groups at $\delta_{\mathrm{H}} 3.76(3 \mathrm{H})$ and $3.77(3 \mathrm{H})$; an acetoxy group at $\delta_{\mathrm{C}} 173.1$ and 21.1 ; four methylene groups at $\delta_{\mathrm{C}} 66.2,62.8,35.9,35.6$; two methine groups at $\delta_{\mathrm{C}} 44.4,40.5$. These structural moieties would constitute an 8,8'-lignane skeleton for compound $\mathbf{2}$, similar to that of secoisolariciresinol ${ }^{[10]}$ except for the substitution in the C-9. The structure of compound 2 was further supported by HMBC spectra (Figure 2). The HMBC correlations of $\mathrm{H}-9 / \mathrm{C}-1$ ", H-2"/C-1" revealed the acetoxy group attached to $\mathrm{C}-9$. The $\mathrm{HMBC}$ correlations of $3-\mathrm{OCH}_{3} / \mathrm{C}-3$, $\mathrm{H}-5 / \mathrm{C}-1, \mathrm{H}-5 / \mathrm{C}-3,33^{\prime}-\mathrm{OCH}_{3} / \mathrm{C}-3$ ', H-5'/C-1', H-5'/C-3', showed the two methoxyl groups located at C-3 and C-3', respectively. The $\left(8 S, 8^{\prime} S\right)$-absolute stereochemistry was confirmed by the specific optical rotation and circular dichroic (CD) curve (positive Cotton effects at 228 and 291 $\mathrm{nm})$ as those of 5-demethoxyniranthin. ${ }^{[11]}$ Therefore, the structure of compound 2 was established to be $\left(8 S, 8^{\prime} S\right)$ 3,3'-dimethoxyligna-4,4',9,9'-tetraol-9-actate. The plane structure of compound 2 was identified already from MS in the literature, ${ }^{[12]}$ but the NMR data were no reported.

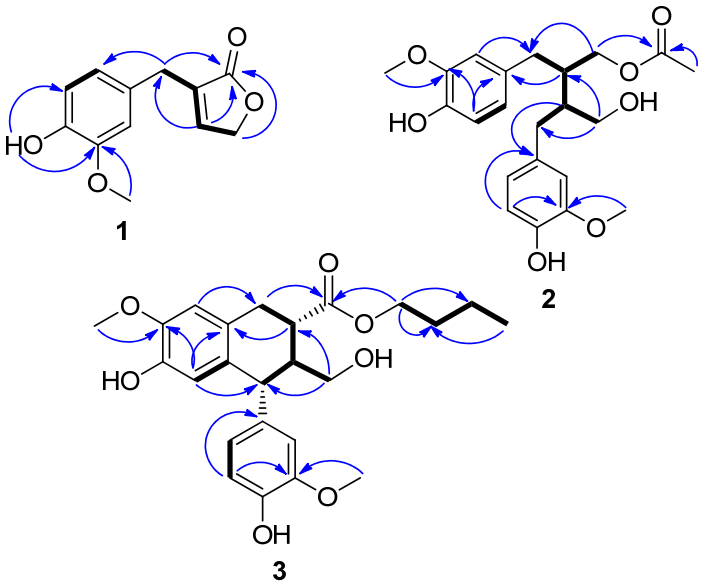

Figure 2 Key ${ }^{1} \mathrm{H}^{-1} \mathrm{H} \operatorname{COSY}(-)$ and $\mathrm{HMBC}(\longrightarrow)$ correlations of compounds $\mathbf{1} \sim \mathbf{3}$

\subsection{Structure identification of compound 3}

Compound 3 was isolated as a yellow gum. Its molecular formula, $\mathrm{C}_{24} \mathrm{H}_{30} \mathrm{O}_{7}$, which indicated 10 degrees of unsaturation, was established from the quasi-molecular ion peak at $m / z 453.1880[\mathrm{M}+\mathrm{Na}]^{+}$(calcd for $\mathrm{C}_{24} \mathrm{H}_{30} \mathrm{O}_{7} \mathrm{Na}$ 453.1889) in the HR-ESI-MS. The IR spectrum of compound 3 indicated the presence of carbonyl group at 1759 $\mathrm{cm}^{-1}$. The ${ }^{1} \mathrm{H}$ NMR spectrum (Table 2) of compound $\mathbf{3}$ displayed two methoxyl signals at $\delta_{\mathrm{H}} 3.79(\mathrm{~s}, 3 \mathrm{H})$ and 3.83 $(\mathrm{s}, 3 \mathrm{H})$, an AMX aromatic system at $\delta_{\mathrm{H}} 6.58(\mathrm{~d}, J=1.9 \mathrm{~Hz}$, $1 \mathrm{H}), 6.64(\mathrm{dd}, J=8.0,1.9 \mathrm{~Hz}, 1 \mathrm{H}), 6.81(\mathrm{~d}, J=8.0 \mathrm{~Hz}$, 
$1 \mathrm{H})$, two aromatic protons at $\delta_{\mathrm{H}} 6.29(\mathrm{~s}, 1 \mathrm{H})$ and $6.54(\mathrm{~s}$, $1 \mathrm{H})$. The ${ }^{13} \mathrm{C}$ NMR and HSQC spectra indicated a carbonyl at $\delta_{\mathrm{C}} 175.8,12$ aromatic carbons at $\delta_{\mathrm{C}} 110.1,111.7,114.5$, $115.8,122.6,126.0,131.6,132.4,144.0,145.2$ and 145.5, 146.9 , two downfield methylene groups at $\delta_{\mathrm{C}} 62.4$ and 65.0 , two methoxyl groups at $\delta_{\mathrm{C}} 56.1$ and 56.1 , three methine carbons at $\delta_{\mathrm{C}} 43.2,46.7$ and 46.9 , three upfield methylene carbons at $\delta_{\mathrm{C}} 19.3,30.8$ and 32.7 , and a methyl carbon at $\delta_{\mathrm{C}} 13.9$. These NMR data suggested that compound 3 might be an aryltetrahydronaphthalene-type lignin. ${ }^{[13-14]}$ ${ }^{1} \mathrm{H}-{ }^{1} \mathrm{H}$ correlated spectroscopy (COSY) (Figure 2) showed the presence of $\mathrm{OCH}_{2} \mathrm{CH}_{2} \mathrm{CH}_{2} \mathrm{CH}_{3}$ moiety. The $\mathrm{HMBC}$ correlations (Figure 2$)$ from $\mathrm{H}-1$ " to $\mathrm{C}-9\left(\delta_{\mathrm{C}} 175.8\right), \mathrm{H}-7$ to C-9, established the location of $\mathrm{OCH}_{2} \mathrm{CH}_{2} \mathrm{CH}_{2} \mathrm{CH}_{3}$ moiety at $\mathrm{C}-9$. The HMBC correlations from $\mathrm{H}-9$ ' to $\mathrm{C}-7$ ', $\mathrm{C}-8$ and C-8' showed an $\mathrm{OH}$ attached to C-9'. The HMBC correlations from $\mathrm{OCH}_{3}-3^{\prime}$ to $\mathrm{C}-3$ ', H-5' to C-3', H-5' to C-1', confirmed the presence of $\mathrm{OCH}_{3}$ at C-3'. Similarly, a methoxy group at C-5 was also assigned. The stereochemistry of different substituent groups on the tetrahydronaphthalene ring was designated using a nuclear overhauser enhancement spectroscopy (NOESY) experiment. The cross-peaks of $\mathrm{H}^{-7} / \mathrm{H}^{\prime} \mathbf{9}^{\prime}, \mathrm{H}-\mathrm{7}^{\prime} / \mathrm{H}-8$ and $\mathrm{H}-8 / \mathrm{H}-9^{\prime}$ indicated that $\mathrm{H}-\mathrm{7}^{\prime}$, H-9' and H-8 were cofacial. The assignments were also buttressed by vicinal coupling constant value of $\mathrm{H}-\mathrm{7}^{\prime}$ and H-8' $(J=10.7 \mathrm{~Hz})$ when the dihedral angle of H-7'-H- $8^{\prime}$ took value close to $180^{\circ}$. The absolute stereochemistry of ( $7^{\prime} R, 8 S, 8^{\prime} S$ )-3 was established by the circular dichroism (CD) spectrum. The positive Cotton effects at 205, 228, $293 \mathrm{~nm}$ and the negative Cotton effects at 227, 239, 277 $\mathrm{nm}$ were very similar to urinatetralin, ${ }^{[11]}$ and it was further confirmed by TD-DFT ECD calculations (Figure 3). In summary, compound 3 was determined to be $\left(7^{\prime} R, 8 S, 8^{\prime} S\right)$ 3',5-dimethoxy-2,7'-cycloligna-4,4',9'-triol-9-acid butyl ester.

The known compounds were identified as matairesinol (4) ${ }^{[15]}$ nortrachelogenin (5), ${ }^{[16]}$ allo-7'-methoxymatairesinol (6), ${ }^{[17]} 7 R$-ethoxymatairesinol $(7),{ }^{[18]} 7$ 'R-hydroxymatairesinol (8), ${ }^{[19]} 7$ 'S-hydroxymatairesinol (9), ${ }^{[19]}$ tsugacetal (10) ${ }^{[20]}$ 1-ethoxy-4-(4'-hydroxy-3'-methoxy-phenyl)-7-methoxy-1,3,3a,4,9,9a-hexahydronaphtho[2,3-c]furan-6-ol
(11) ${ }^{[21]} \alpha$-conidendrin (12), ${ }^{[22]} 8$-hydroxy- $\alpha$-conidendrin (13) ${ }^{[23]}$ 4,4'-dihydroxy-3,3'-dimethoxy-7-one-lignan-9,9'olid (14), ${ }^{[24]} 8$-hydroxyoxomatairesinol (15), ${ }^{[25]} 8$-hydroxy$\alpha$-conidendric acid methyl ester (16) ${ }^{[23]}$ epinortrachelogenin $(\mathbf{1 7}),{ }^{[26]}$ isolariciresinol (18), ${ }^{[27]}$ burselignan (19) ${ }^{[27]}$ 3-(2,4-dihydroxy-3-methoxybenzyl)-4-(4-hydroxy-3-methoxybenzy1)tetrahydrofuran $(\mathbf{2 0}),{ }^{[28]}$ cedrusin $(\mathbf{2 1}),{ }^{[29]}$ and 7'-hydroxyisolappaol A (22). ${ }^{[30]}$

All these new compounds were evaluated for their cytotoxicity against A172, SHSY5Y and Hela cells using MTT method. But these compounds are inactive $\left(\mathrm{IC}_{50}>50\right.$ $\mu \mathrm{mol} / \mathrm{L})$ for all cell lines. Compounds $\mathbf{1} \sim \mathbf{3}$ were evaluated for their activity of promoting gastrointestinal motility of zebrafish treated with Nile red. Compound 3 significantly promoted the Nile red excretion at doses $>8$ and $>24$ $\mu \mathrm{mol} / \mathrm{L}$. Compound 3 promoted the gastrointestinal motility weaken, at 50 and $5 \mu \mathrm{mol} / \mathrm{L}$ atropine, compared with the test result no atropine at $50 \mu \mathrm{mol} / \mathrm{L}$. These results showed that compound $\mathbf{3}$ might promote the gastrointestinal motility of zebrafish via acted on the cholinergic nervous system (Figure 4).

\section{Conclusions}

The phytochemical investigation of $N$. longibracteata gave a new benzyl furanone derivate (1), two new lignans 2 $\mathbf{3}$ and 19 known lignans compounds $\mathbf{4} \sim \mathbf{2 2}$. Compound 1 was a novel furanone derivate, and it was first isolated from plants as natural product skeleton as well as we know. ${ }^{[9]}$ Compound $\mathbf{1}$ maybe the degradation of benzyl product of dibenzylbutyrolactone lignan. Compound $\mathbf{3}$ has the function of promoting gastrointestinal motility of zebrafish to excrete Nile red at doses 8 and $24 \mu \mathrm{mol} / \mathrm{L}$ by means of acting on the cholinergic nervous system.

\section{Experimental}

\subsection{Instruments and reagents}

UV spectra were recorded on a Perkin-Elmer Lambda 35 UV-Vis spectrophotometer. CD spectra were recorded on a Chirascan circular dichroism spectrometer (Applied Photophysics Ltd, Leatherhead, U.K.). HR-ESI-MS spectra

Table $2{ }^{1} \mathrm{H}$ NMR and ${ }^{13} \mathrm{C}$ NMR spectral data of compound $3\left(400 / 100 \mathrm{MHz}\right.$, in $\left.\mathrm{CDCl}_{3}\right)$

\begin{tabular}{|c|c|c|c|c|c|}
\hline Positio & $\delta_{\mathrm{H}}(J$ in $\mathrm{Hz})$ & $\delta_{\mathrm{C}}$ & Position & $\delta_{\mathrm{H}}(J$ in $\mathrm{Hz})$ & $\delta_{\mathrm{C}}$ \\
\hline 1 & & 126.0 & $4^{\prime}$ & & 144.5 \\
\hline 2 & & 132.4 & $5^{\prime}$ & $6.81(\mathrm{~d}, 8.0,1 \mathrm{H})$ & 114.5 \\
\hline 3 & $6.29(\mathrm{~s}, 1 \mathrm{H})$ & 115.8 & $6^{\prime}$ & $6.64(\mathrm{dd}, 8.0,1.9,1 \mathrm{H})$ & 122.6 \\
\hline 4 & & 144.0 & $7^{\prime}$ & $3.91(\mathrm{~d}, 10.7,1 \mathrm{H})$ & 46.7 \\
\hline 5 & & 145.2 & $8^{\prime}$ & $2.65,2.92$ (overlapped, $1 \mathrm{H})$ & 43.2 \\
\hline 6 & $6.54(\mathrm{~s}, 1 \mathrm{H})$ & 110.1 & $9^{\prime}$ & $3.56(\mathrm{dd}, 11.8,3.0,1 \mathrm{H}) 3.43(\mathrm{dd}, 11.8,3.5,1 \mathrm{H})$ & 62.7 \\
\hline 7 & $3.21(\mathrm{dd}, 15.7,11.5,1 \mathrm{H}) ; 2.86 \sim 2.93$ (overlapped, $1 \mathrm{H}$ ) & 32.7 & $1 "$ & $4.09 \sim 4.15(\mathrm{~m}, 2 \mathrm{H})$ & 65.0 \\
\hline 8 & $2.08 \sim 2.17(\mathrm{~m}, 1 \mathrm{H})$ & 46.9 & $2^{\prime \prime}$ & $1.59 \sim 1.65(\mathrm{~m}, 2 \mathrm{H}$ & 30.8 \\
\hline 9 & & 175.8 & $3 "$ & $1.33 \sim 1.42(\mathrm{~m}, 2 \mathrm{H}$ & 19.3 \\
\hline $1^{\prime}$ & & 136.6 & $4 "$ & $0.92(\mathrm{t}, 7.4,3 \mathrm{H})$ & 13.9 \\
\hline $2^{\prime}$ & $6.58(\mathrm{~d}, 1.9,1 \mathrm{H})$ & 111.7 & $5-\mathrm{OCH}_{3}$ & $3.83(\mathrm{~s}, 3 \mathrm{H})$ & 56.1 \\
\hline $3^{\prime}$ & & 146.9 & 3'- $\mathrm{OCH}_{3}$ & $3.79(\mathrm{~s}, 3 \mathrm{H})$ & 56.1 \\
\hline
\end{tabular}




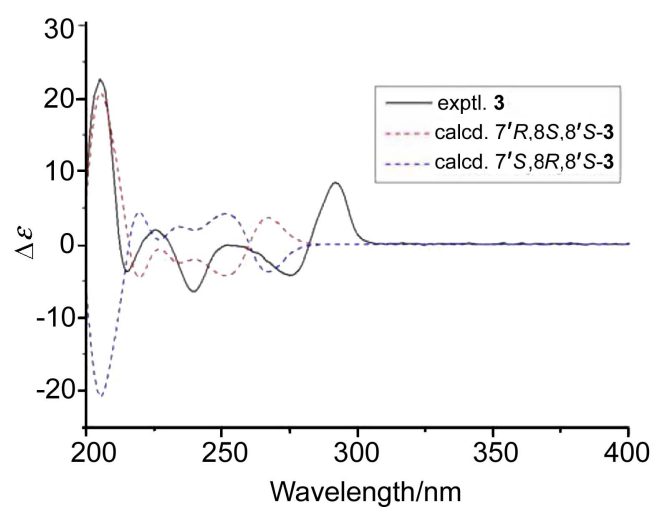

Figure 3 Calculated ECD spectra of $7^{\prime} R, 8 S, 8^{\prime} S-3$

(a)

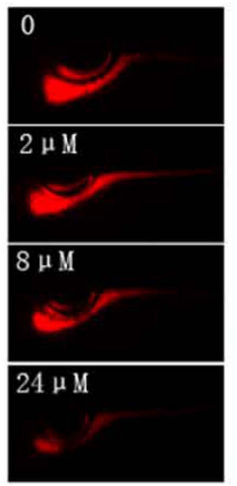

(b)
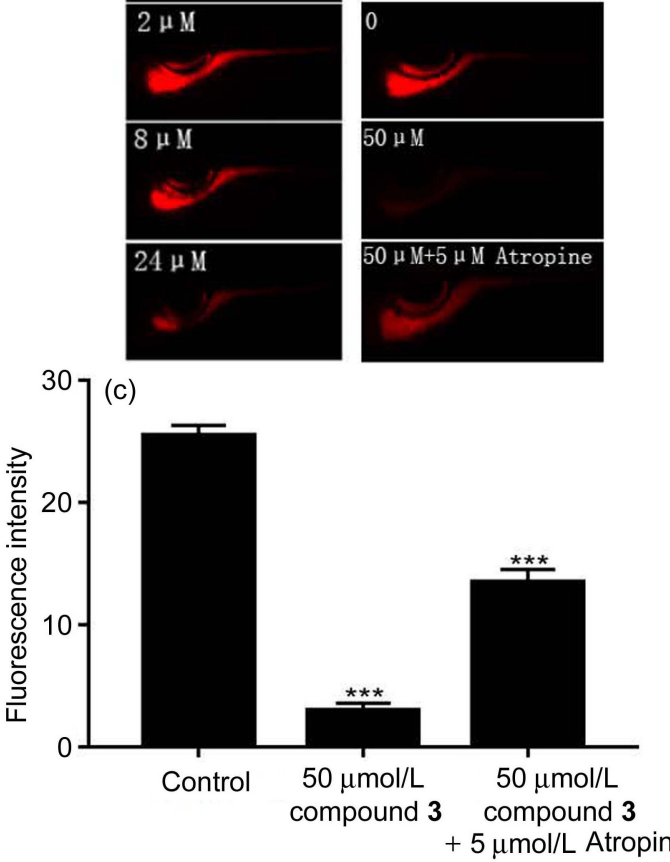

Figure 4 (a) Effect of compound 3 on the gastrointestinal motility of zebrafish. (b) and (c) interfering effect of atropine on the gastrointestinal activation of compound 3. Indicates $p<0.001$ when compared with the control

were measured on a Bruker MicrO TOF-Q II mass spectrometer. Optical rotations were determined on a Perkin-Elmer-241 polarimeter (Perkin Elmer, Inc., Waltham, MA, USA). IR spectra were measured on a PerkinElmer one FT-IR spectrometer (KBr). 1D NMR and 2D NMR spectra were recorded on a Bruker-AVANCE III-400 or an Agilent DD2400-MR instrument using TMS as the internal reference. Column chromatography was performed using silica gel (300 400 mesh, Qingdao marine Chemical Ltd., Qingdao, P. R. China). Semi-preparative high-pressure liquid chromatography (HPLC) was performed on a LC 3000 system (Beijing ChuangXingTongHeng Science and Technology Co., Ltd.) equipped with ODS column ( $5 \mu \mathrm{m}$, i.d. $10 \mathrm{~mm} \times 250 \mathrm{~mm}, \mathrm{YMC}$ and $\mathrm{H} \& \mathrm{E})$.

\subsection{Plant materials}

The heartwood of this plant was collected from Huang Sang Nature Reserve in Hunan province, China, in August 2016, and identified as Nothotsuga longibrteata (W. C. Cheng) $\mathrm{Hu}$ ex C. N. Page by Prof. Fa-Ming Wu (Zunyi Medical University). A voucher specimen (ZMC No. 20160814) was deposited at School of Pharmacy of Zunyi Medical University.

\subsection{Extraction and separation}

The air-dried and finely ground heartwood of $N$. longibracteata $(5.0 \mathrm{~kg})$ was extracted with $95 \%$ ethanol $(25 \mathrm{~L})$ for three times at room temperature $(5 \mathrm{~d}$ each). The ethanol portion was evaporated under reduced pressure to get a crude extract ( $900 \mathrm{~g}$ ), which was further suspended in warm distilled water $(2.0 \mathrm{~L})$ and extracted successively with petroleum ether, EtOAc, and $n-\mathrm{BuOH}$ (repeat each solvent 3 times), respectively. The EtOAc extract (205 g) was subjected to silica gel column chromatography $(80 \mathrm{~mm} \times 600$ $\mathrm{mm}, 400 \mathrm{~g}, 300 \sim 400 \mathrm{mesh})$, eluted with a gradient of petroleum ether-EtOAc $(V: V=10: 1 \rightarrow 1: 2)$ to afford 6 fractions (Fr.1 $\sim$ Fr.6).

Fr.4 was further separated by silica gel column chromatography to get 3 fractions (Fr.4.1 Fr.4.3). Fr.4.1 was purified by a Sephadex LH-20 column chromatography $(\mathrm{MeOH})$ and divided into 8 subfractionses (Fr.4.1.1 Fr.4.1.8). Fr.4.1.3 was further purified by semi-preparative HPLC with $\mathrm{MeOH}-\mathrm{H}_{2} \mathrm{O}(V: V=60: 40)$ to yield compound $7\left(t_{\mathrm{R}} 10.3 \mathrm{~min}, 10.5 \mathrm{mg}\right)$. Fr.4.1.5 was further purified by semi-preparative HPLC with $\mathrm{MeOH}-\mathrm{H}_{2} \mathrm{O}(V: V=60$ : 40) to get compounds $\mathbf{1 0}\left(t_{\mathrm{R}} 9.7 \mathrm{~min}, 10.9 \mathrm{mg}\right)$ and $\mathbf{1 1}\left(t_{\mathrm{R}}\right.$ $14.3 \mathrm{~min}, 14.1 \mathrm{mg})$. Fr.4.2 was purified by semi-preparative HPLC with $\mathrm{MeOH}-\mathrm{H}_{2} \mathrm{O}(V: V=50: 50)$ to yield 6 subfractionses (Fr.4.2.1 Fr.4.2.6). Fr.4.2.3 was further purified by semi-preparative $\mathrm{HPLC}$ with $\mathrm{MeOH}-\mathrm{H}_{2} \mathrm{O}(V: V=$ $58: 42)$ to obtain compound $5\left(t_{\mathrm{R}} 8.7 \mathrm{~min}, 17.6 \mathrm{mg}\right)$. Fr.4.2.5 was further purified by semi-preparative HPLC with $\mathrm{MeOH}-\mathrm{H}_{2} \mathrm{O}(V: V=65: 35)$ to obtain compound 4 $\left(t_{\mathrm{R}} 17.1 \mathrm{~min}, 30.6 \mathrm{mg}\right)$. Fr.4.2.6 was repeated recrystallization to get compound $12(20.5 \mathrm{mg})$.

Fr.5 was further separated by silica gel column chromatography to get 2 fractions (Fr.5.1 Fr.5.2). Fr.5.1 was purified by a Sephadex LH-20 column chromatography $(\mathrm{MeOH})$ and divided into 10 subfractionses (Fr.5.1.1 Fr.5.1.10). Fr.5.1.2 was further purified by semi-preparative HPLC with $\mathrm{MeOH}-\mathrm{H}_{2} \mathrm{O}(V: V=60: 40)$ to yield compounds $16\left(t_{\mathrm{R}} 10.3 \mathrm{~min}, 10.5 \mathrm{mg}\right)$ and $6\left(t_{\mathrm{R}} 18.3 \mathrm{~min}, 10.5\right.$ $\mathrm{mg})$. Fr.5.1.3 was further purified by semi-preparative HPLC with $\mathrm{MeOH}-\mathrm{H}_{2} \mathrm{O}(V: V=55: 45)$ to get compound $1\left(t_{\mathrm{R}} 9.7 \mathrm{~min}, 10.9 \mathrm{mg}\right)$. Fr.5.1.6 was purified by semipreparative HPLC with $\mathrm{MeOH}-\mathrm{H}_{2} \mathrm{O}(V: V=40: 60)$ to obtain compound $13\left(t_{\mathrm{R}} 24.3 \mathrm{~min}, 20.3 \mathrm{mg}\right)$. Fr.5.2 was separated by semi-preparative HPLC with $\mathrm{MeOH}-\mathrm{H}_{2} \mathrm{O}$ $(V: V=23: 77 \rightarrow 62: 38$ ) to yield 7 subfractionses (Fr.5.2.1 Fr.5.2.7). Fr.5.2.2 was further purified by semi-preparative $\mathrm{HPLC}$ with $\mathrm{MeOH}-\mathrm{H}_{2} \mathrm{O}(V: V=33: 67)$ 
to obtain compounds $9\left(t_{R} 27.1 \mathrm{~min}, 16.5 \mathrm{mg}\right)$ and $\mathbf{8}\left(t_{\mathrm{R}} 30.0\right.$ $\mathrm{min}, 14.9 \mathrm{mg})$. Fr.5.2.3 was further purified by semi-preparative HPLC with $\mathrm{MeOH}-\mathrm{H}_{2} \mathrm{O}(V: V=42: 58)$ to obtain compound $14\left(t_{\mathrm{R}} 24.1 \mathrm{~min}, 19.5 \mathrm{mg}\right)$. Fr.5.2.4 was further purified by semi-preparative HPLC with $\mathrm{MeOH}-\mathrm{H}_{2} \mathrm{O}(V$ : $V=45: 55)$ to get compound $17\left(t_{\mathrm{R}} 32.6 \mathrm{~min}, 17.5 \mathrm{mg}\right)$. Fr.5.2.5 was further purified by semi-preparative HPLC with $\mathrm{MeOH}-\mathrm{H}_{2} \mathrm{O}(V: V=42: 58)$ to obtain compound 15 $\left(t_{\mathrm{R}} 35.4 \mathrm{~min}, 20.3 \mathrm{mg}\right)$.

Fr.6 was further separated by silica gel column chromatography to get 5 fractions (Fr.6.1 $\sim$ Fr.6.5). Fr.6.2 was purified by Sephadex LH-20 column chromatography $(\mathrm{MeOH})$ and divided into 8 subfractionses (Fr.6.2.1 Fr.6.2.8). Fr.6.2.4 was further purified by semi-preparative HPLC with $\mathrm{MeOH}-\mathrm{H}_{2} \mathrm{O}(V: V=23: 77)$ to yield compound $18\left(\mathrm{t}_{\mathrm{R}} 18.5 \mathrm{~min}, 23.5 \mathrm{mg}\right)$. Fr.6.2.5 was isolated by semi-preparative HPLC with $\mathrm{MeOH}-\mathrm{H}_{2} \mathrm{O}(V: V=37$ : $63 \rightarrow 50: 50)$ to obtain 14 subfractionses (Fr.6.2.5.1 Fr.6.2.5.14). Fr.6.2.5.3 was further purified by semipreparative HPLC with $\mathrm{MeOH}-\mathrm{H}_{2} \mathrm{O}(V: V=25: 75)$ to get compounds $21\left(t_{\mathrm{R}} 23.9 \mathrm{~min}, 5.4 \mathrm{mg}\right)$ and $\mathbf{1 9}\left(t_{\mathrm{R}} 25.0 \mathrm{~min}, 3.7\right.$ $\mathrm{mg})$. Fr.6.2.5.6 was purified by semi-preparative HPLC with $\mathrm{MeOH}-\mathrm{H}_{2} \mathrm{O}(V: V=38: 62)$ to obtain compound 20 $\left(t_{\mathrm{R}} 42.1 \mathrm{~min}, 12.4 \mathrm{mg}\right.$ ). Fr.6.2.5.8 was further purified by semi-preparative HPLC with $\mathrm{MeOH}-\mathrm{H}_{2} \mathrm{O}(V: V=47: 53)$ to yield compound $22\left(t_{\mathrm{R}} 47.7 \mathrm{~min}, 9.1 \mathrm{mg}\right)$. Fr.6.4 was separated by semi-preparative HPLC with $\mathrm{MeCN}-\mathrm{H}_{2} \mathrm{O}(V$ : $V=35: 65)$ to yield 5 subfractionses $(\mathrm{Fr} .6 .4 .1 \sim$ Fr.6.4.5). Fr.6.4.3 was further purified by semi-preparative HPLC with $\mathrm{MeCN}_{-} \mathrm{H}_{2} \mathrm{O}(V: V=35: 65)$ to obtain compounds 2 $\left(t_{\mathrm{R}} 37.1 \mathrm{~min}, 10.5 \mathrm{mg}\right)$ and $\mathbf{3}\left(t_{\mathrm{R}} 45.9 \mathrm{~min}, 13.7 \mathrm{mg}\right)$.

3-(4'-Hydroxy-3'-methoxybenzyl)-2(5H)-furanone (1): Brown gum; $[\alpha]_{\mathrm{D}}^{20} 0$ (c 0.01, MeOH); UV (MeOH) $\lambda_{\max }[\log$

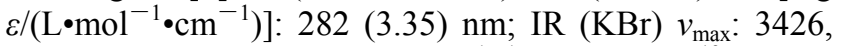
1746, 1514, 1070, 1040, $667 \mathrm{~cm}^{-1}$; ${ }^{1} \mathrm{H}$ NMR and ${ }^{13} \mathrm{C}$ NMR data, Table 1; HR-ESI-MS $m / z$ : $221.0809[\mathrm{M}+\mathrm{H}]^{+}$(calcd for $\left.\mathrm{C}_{12} \mathrm{H}_{13} \mathrm{O}_{4}^{+}, 221.0808\right)$.

$\left(8 S, 8^{\prime} S\right)-3,3$ '-Dimethoxyligna-4,4',9,9'-tetraol-9-actate (2): Brown gum; $[\alpha]_{\mathrm{D}}^{20}+20($ c $0.01, \mathrm{MeOH}) ; \mathrm{UV}(\mathrm{MeOH})$

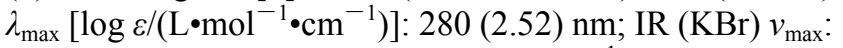
$3432,1720,1807,1516,1269,1031 \mathrm{~cm}^{-1}$; CD (c 6.00× $\left.10^{-5} \mathrm{~mol} / \mathrm{L}, \mathrm{MeOH}\right) \lambda_{\max }\left[\Delta \varepsilon /\left(\mathrm{deg} \cdot \mathrm{cm}^{2} \cdot \mathrm{dmol}^{-1}\right)\right] 205(+$ 4.28), $211(-9.21), 228(+2.61), 291(+0.94) \mathrm{nm} ;{ }^{1} \mathrm{H}$ NMR and ${ }^{13} \mathrm{C}$ NMR data see Table 1; HR-ESI-MS calcd for $\mathrm{C}_{22} \mathrm{H}_{28} \mathrm{O}_{7} \mathrm{Na}[\mathrm{M}+\mathrm{Na}]^{+}$427.1733, found 427.1714.

(7'R,8S,8'S)-3',5-Dimethoxy-2,7'-cycloligna-4,4', 9'-triol9-acid butyl ester (3): Yellow gum; $[\alpha]_{\mathrm{D}}^{20}-24(c) 0.02$, $\mathrm{MeOH}) ; \mathrm{UV}(\mathrm{MeOH}) \lambda_{\max }\left[\log \varepsilon /\left(\mathrm{L} \cdot \mathrm{mol}^{-1} \cdot \mathrm{cm}^{-1}\right)\right]: 285$ (2.42) nm; IR (KBr) $v_{\max }: 3410,1759,1516,1271,1218$, $994 \mathrm{~cm}^{-1} ; \mathrm{CD}\left(c \quad 6.00 \times 10^{-5} \mathrm{~mol} / \mathrm{L}, \mathrm{MeOH}\right) \lambda_{\max }$ $\left[\Delta \varepsilon /\left(\mathrm{deg} \cdot \mathrm{cm}^{2} \cdot \mathrm{dmol}^{-1}\right)\right] 206(+22.21), 225(+2.02), 240$ $(-6.39), 274(-4.05), 292(+8.50) \mathrm{nm} ;{ }^{1} \mathrm{H}$ NMR and ${ }^{13} \mathrm{C}$ NMR data see Table 2; HR-ESI-MS calcd for $\mathrm{C}_{24} \mathrm{H}_{30} \mathrm{O}_{7} \mathrm{Na}$ $[\mathrm{M}+\mathrm{Na}]^{+} 453.1889$, found 453.1880 .

\subsection{Cytotoxicity assay}

Three human cancer cell lines, A172, SHSY5Y and
Hela cells, were used in the cytotoxicity assay. The cytotoxicity assay was performed using the MTT method as literature. ${ }^{[31]}$ Using cis-platin and taxol as positive control, all tests were performed in triplicate.

\subsection{Gastrointestinal motility of zebrafish}

Zebrafish culture and experimental procedure of gastrointestinal motility were performed as literature. ${ }^{[32]}$

\subsection{Computational details}

The theoretical calculation of compound $7^{\prime} R, 8 S, 8^{\prime} S-3$ was carried out as described previously using Gaussian $16 .{ }^{[33]}$ Conformational analysis was performed using Conflex 8 (Boltzman Jump, Smart Minimizer using the MMFF). All configurations (relative energy $<41.9 \mathrm{~kJ} / \mathrm{mol}$ ) were used in optimizations at the B3LYP/6-31G(d,p) in $\mathrm{MeOH}$. The theoretical calculation of ECD was performed using TDDFT at the B3LYP/6-31G(2d,2p) level in MeOH. ${ }^{[34]}$ SpecDis 1.71 was used to sum up single ECD spectra after a Boltzmann statistical weighting, and for the Gauss curve generation $(\sigma=0.2 \mathrm{eV})$ and the comparison with experimental data.

Supporting Information 1D NMR, 2D NMR, HR-ESIMS spectra of compounds $\mathbf{1} \sim \mathbf{3}$, and CD spectra of compounds 2 and 3. The Supporting Information is available free of charge via the Internet at http://sioc-journal.cn.

\section{References}

[1] Qiu, Y. J.; Yi, G. M.; Ning, Z. L.; Huang, H. W. J. Plant Resour Environ. 2011, 20, 53.

[2] Zhang, H. Y.; Zhang, Z. Y. The Chinese Traditional Medicine Resource Records, Science Press, Beijing, 1994 (in Chinese). (张惠源, 张志英, 中国中药资源志要, 科学出版社, 北京, 1994.)

[3] Xiao, S. J.; Shi, D. B.; Yuan, Z. L.; Chen, Y. Z.; Zhang, M. S.; Ding, L. S.; Zhou, Y. Chin. J. Org. Chem. 2016, 36, 1686 (in Chinese). (肖世基，史大斌，袁泽利，陈永正，张茂生，丁立生，周燕，有 机化学, 2016, 36, 1686.)

[4] Liu, G. Y.; Nie, Q. F.; Weng, Q. H.; Zhang, M. S.; Ding, L. S.; Zhou, Y.; Chen, F.; Xiao, S. J. Biochem. Syst. Ecol. 2018, 77, 4.

[5] Xiao, S. J.; Chen, F.; Ding, L. S.; Zhou, Y. Chin. J. Nat. Med. 2015, 13,65 .

[6] Xiao, S. J.; Zhang, M. S.; Guo, D. L.; Chen, F.; Zhou, Y.; Ding, L. S. Chin. Chem. Lett. 2017, 28, 1049.

[7] Zhang, M. S.; Deng, Y.; Fu, S. B.; Guo, D. L.; Xiao, S. J. Molecules 2018, 23, 1539.

[8] Xiao, S. J.; Guo, D. L.; Xia, B.; Allen, S.; Gu, Y. C.; Chen, F.; Ding, L. S.; Zhou, Y. Planta Med. 2016, 82, 723.

[9] Schmidt, B.; Wolf, F.; Ehlert, C. J. Org. Chem. 2016, 81, 11235.

[10] Sugahara, T.; Yamauchi, S.; Kondo, A.; Ohno, F.; Tominaga, S.; Nakashima, Y.; Kishida, T.; Akiyama, K.; Maruyama, M. Biosci. Biotechnol. Biochem. 2007, 71, 2962.

[11] Chang, C. C.; Lien, Y. C.; Liu, K. C. S. C.; Lee, S. S. Phytochemistry 2003, 63, 825 .

[12] Yamamoto, S.; Otto, A.; Simoneit, B. R. J. Mass Spectrom. 2004 39, 1337.

[13] Li, N.; Wu, J. L.; Hasegawa, T.; Sakai, J.; Bai, L. M.; Wang, L. Y.; Kakuta, S.; Furuya, Y.; Ogura, H.; Kataoka, T.; Tomida, A.; Tsuruo, T.; Ando, M. J. Nat. Prod. 2007, 70, 544.

[14] Wang, L. N.; Qin, L. L.; He, J. L.; Li, X. H.; Cao, Z. X.; Gu, Y. C.; Deng, F.; Deng, Y. J. Asian Nat. Prod. Res. 2019, 21, 999. 
[15] Prabhu, B. R.; Mulchandani, N. B. Phytochemistry 1985, 24, 329

[16] Tiwari, A. K.; Srinivas, P. V.; Kumar, S. P.; Rao, J. M. J. Agric. Food Chem. 2001, 49, 4642

[17] Kawamura, F.; Miyachi, M.; Kawai, S.; Ohashi, H. J. Wood Sci. 1998, 44, 47.

[18] Eklund, P. C.; Sundell, F. J.; Smeds, A. I.; Sjoholm, R. E. Org. Biomol. Chem. 2004, 2, 2229.

[19] Fischer, J.; Reynolds, A. J.; Sharp, L. A.; Sherburn, M. S. Org. Lett. 2004, 6, 1345

[20] Fang, J.; Wei, K.; Cheng, Y.; Cheng, M.; Wang, Y. Phytochemistry 1985, 24, 1363

[21] Cambie, R. C.; Clark, G. R.; Craw, P. A.; Jones, T. C.; Rutledge, P. S.; Woodgate, P. D. Aust. J. Chem. 1985, 38, 1631.

[22] Zhao, Y. X.; Luo, X. D.; Zhou, J. Acta Bot. Yunnanica 2004, 26, 229 (in Chinese).

(赵友兴, 李承森, 罗晓东, 刘玉清, 周俊, 云南植物研究, 2004, 26, 229.)

[23] Kawamura, F.; Kawai, S.; Ohashi, H. Phytochemistry 1997, 44, 1351.

[24] Zao, Y. X.; Li, C. S.; Luo, X. D.; Liu, Y. Q.; Zhou, J. Acta Bot. Yunnanica 2005, 27, 217 (in Chinese).

(赵友兴, 李承森, 罗晓东, 刘玉清, 周俊, 云南植物研究, 2005, 27, 217.)

[25] Kawamura, F.; Kawai, S.; Ohashi, H. Phytochemistry 2000, 54,
439.

[26] Yamauchi, S.; Sugahara, T.; Nakashima, Y.; Okada, A.; Akiyama, K.; Kishida, T.; Maruyama, M.; Masuda, T. Biosci. Biotechnol. Biochem. 2006, 70, 1934.

[27] Jutiviboonsuk, A.; Zhang, H.; Tan, G. T.; Ma, C.; Van Hung, N.; Manh Cuong, N.; Bunyapraphatsara, N.; Soejarto, D. D.; Fong, H. H. Phytochemistry 2005, 66, 2745.

[28] Estévez-Braun, A.; Estévez-Reyes, R.; González-Pérez, J. A.; González, A. G. J. Nat. Prod. 1995, 58, 887.

[29] Bi, Y. F.; Zhen, X. K.; Liu, H. M.; Feng, W. S.; Ji, C. R.; Zhang, Y. Z. Acta Pharm. Sin. 2001, 33, 832 (in Chinese). (毕跃峰, 郑晓珂, 刘宏民, 冯卫生, 冀春茹, 张勇忠, 药学学报, 2001, 33, 832.)

[30] Yang, M.; Wang, C. M.; Zhang, Q.; Han, Y. F.; Jia, Z. J. Pharmazie 2004, 59, 972.

[31] Lu, C. Y.; Li, H. X.; Li, S.; Qiu, L.; Yu, S.; Cao, Z. X.; Guo, D. L.; Deng, Y. Nat. Prod. Commun. 2017, 12, 1463.

[32] He, X.; Yang, J.; Qiu, L.; Feng, D.; Ju, F.; Tan, L.; Li, Y. Z.; Gu, Y. C.; Zhang, Z.; Guo, D. L.; Deng, Y. Molecules 2019, 24, 299.

[33] Li, S.; Chen, J. F.; Qin, L. L.; Li, X. H.; Cao, Z. X.; Gu, Y. C.; Guo, D. L.; Deng, Y. J. Asian Nat. Prod. Res. 2020, 22, 138.

[34] Li, X. H.; Hu, H. W.; Tan, L.; Wu, W. L.; Cao, Z. X.; Gu, Y. C.; Deng, Y.; Guo, D. L. Nat. Prod. Commun. 2018, 13, 1419. 